\title{
Association of Makhana (Euryale Ferox Salisb) with Macrophyte Weeds in Katihar District of Bihar, India
}

Meenu Sodi ${ }^{1}$, Sanjib Kumar ${ }^{2 *}$

${ }^{1}$ Assistant Professor (Guest), B.S.S.College, Supaul - 852131, Bihar, India

${ }^{2}$ Prof. of Botany and Principal, B.S.S.College, Supaul - 852131, Bihar, India

DOI: $10.36347 /$ sjavs.2020.v07i11.001

| Received: 12.10.2020 | Accepted: 29.10.2020 | Published: 05.11.2020

*Corresponding author: Sanjib Kumar

Abstract

Original Research Article

Euryale ferox Salisb. (makhana / gorgon nut) is an important annual wetland floating leaf angiospermic macrophyte which grows naturally in wild forms in aquatic bodies. It is also cultivated in ponds, low land stagnant water, fields etc. This plant is especially cultivated in northern Bihar, West Bengal, Manipur and MP for its seeds. Roasted / popped seeds of makhana (puffs) are tasty, light, crispy, fatless, aphrodisiac, spermatogenic and with high carbohydrate, protein and mineral contents. Therefore, makhana puffs have especially become a delicacy in the diet of riches and are in high demand in western and gulf countries.Bihar is the largest producer (90\%) of makhana in India and the world too. In north Bihar, Katihar district is known for its fine network of Himalayas' emanating rivers as well as a large number of other natural and man- made aquifers.Euryale ferox (makhana) is the most common aquatic macrophyte grown as cash crop in the non-calcareous belts of Koshi and Mahananda rivers of Katihar. In the initial stage of growth of makhana crop its water bodies are heavily infested with aquaphyte weeds. Hence, a periodic manual, herbal or chemical weeding of aquatic bodies in early stages is essential for the establishment of makhana seedlings. In the present study, altogether 35 macrophyte species belonging to 33 genera of angiosperms and pteridophytes were recorded from makhana crop fields. The imortant macrophytic weeds were Eichhornia crassipes, Monocharia hastata, Ceratophyllum demursum, Nelumbo nucifera, Nymphaea nauchali etc. were recorded in the present investigation. These aquatic macrophytes pose a great threat to the growth of makhana and considerably reduce the crop yield. These aquaphytic weeds also show detrimental allelopathic effects on the cultivation of makhana. However, makhana has the great potentiality as a solution for poverty alleviation and livelihood security especially for economically poor rural people who thrive in wetland areas.

Key words: Makhana, weedy macrophytes, association, yield reduction, livelihood security.

Copyright $\odot 2020$ The Author(s): This is an open-access article distributed under the terms of the Creative Commons Attribution 4.0 International License (CC BY-NC 4.0) which permits unrestricted use, distribution, and reproduction in any medium for non-commercial use provided the original author and source are credited.

\section{INTRODUCTION}

Euryale ferox Salisb. (makhana/gorgon nut/prickly water lily) is an important wetland macrophyte which grows naturally in wild form or cultivated in pond, low land stagnant water, fields etc. It is one of the important underutilized aquatic food crop next to deep-water rice and water chestnut [1]. It belongs to water lily family Nymphaeaceae, although it is occasionally regarded under a distinct family Euryalaceae also. It is a monotypic genus [2] growing in the shallow littoral parts of flood plain wetland which are of perennial nature. The plant is widly prevalent in tropical and sub-tropical regions accomplished with humid to sub-humid environment and mainly cultivated as a source of starch protein [3, 4]. It provides livelihood to the fisherman and other related communities [5, 6]. On account being fatless aphrodisiac, spermatogenic and high carbohydrate and protein content makhana is in high demand in western and gulf countries [7]. Makhana is a forced annual plant and aquatic bio-resource of India. Bihar is the leading producer of makhana and it produces about $90 \%$ of makhana in India [8]. North Bihar of India ranks first $(80 \%)$ not only in Bihar but also in the world in the production of makhana. Production of makhana pop in state is estimated to be around 20,000 MT with major producing district being Darbhanga, Madhubani, Purnea and Katihar. Wetlands in the region of North Bihar has $2,69,418$ ha comprising an average of $4.96 \%$ of its total of its geographical area. In Bihar district Madhubani occupies the highest share of total production of makhana pop, which contributes about $20 \%$ of total production in the state i.e. 3000 MT followed by Katihar 18\%, Darbhanga, Purnea and others [9]. Maximum wetland area in Katihar district is 21,011 ha i.e. about $10.30 \%$ of the geographical area of the district 
[10]. Makhana cultivation in clusters of Katihar is done in two systems pond systems and field systems [11].

Euryale ferox Salisb. is ecologically classified as floating leaf emergent macrophyte or as a rooted floating macrophyte (aerohydatophyte). Since makhana is an aquatic crop therefore, several other aquaphytes/aquatic macrophytes are also used to grow in association with makhana. They are usually harmful to makhana plants by competing for nutrients, sunlight and space. But on the other hand when they decay during grand growth period of makhana then they become helpful by supporting nutrients of organic origin to makhana plants. Some macrophytes associated with makhana grow up to maturity of makhana plant and are really competitors. They may add nutrients for subsequent crops but need to be removed to get good growth of makhana. It has been recorded that due to gregarious invasion of Eichhorniacrassipes, Pistia stratiotes, Lemmna perpusilla, Monochoria hastate, Salvinia molesta, Cyprus exaltatus, Alternanthara philoxeroid and Typha angustata,Euryale ferox have been disappeared from previously inhabited water in West Bengal [12]. Makhana prefers tropical and subtropical climate, temperature between $20{ }^{\circ} \mathrm{C}-35{ }^{\circ} \mathrm{C}$, humidity between $50 \%-90 \%$ and rainfall between 100 $\mathrm{cm}-250 \mathrm{~cm}$ [13] and favoured by neutral $\mathrm{pH}$ [14]. Physicoclimatic conditions, soil characterisation, rainfall, temperature and terrain favour makhana cultivation in North Bihar. Euryale ferox Salisb. (Makhana) is the foremost aquatic macrophyte grown as cash crop in the non-calcareous Koshi- Mahananda belt of Katihar.In the surveys of makhana cultivated areas of Katihar district during 2016 - 2019, almost all makhana growing water bodies were found to be moderately or heavily infested by the aquatic macrophytes. So both from ecological and agricultural point of views it was thought necessary to know the status and impact of aquatic macrophyte weeds on makhana production as makhana crop is rapidly infested by weeds too in the initial stage of establishment of the seedling.

\section{MATERIALS AND METHODS}

A detailed survey was conducted during 20162019 in makhana cultivated fields/ponds situated in wetland areas of 9 pounds of three blocks of Katihar district of Bihar (Table - 1, Plate - 1). The survey involved methods of observations, interactions, interviews along with individual group discussion to identify major cluster producing makhana and existing cultivation system and processing operation including collection of aquatic macrophytes. Macrophyte collection is done seasonally and identified with the help of standard books [15-19] and consulting different herbaria of NBRI, Lucknow and PG Dept of Botany TMBU, Bhagalpur.

Macrophytes associated with makhana were directly collected from different sites of makhana cultivated fields /ponds while those from deeper water with the help of long handled hook. Collected specimens were thoroughly washed at the spots, excess water soaked with filter paper, kept in the polythene bags lined with filter paper and brought to the laboratory. On the same day, the specimens were shade dried, kept in the sun for few minutes and then put in herbarium pressure for making herbarium of them. These herbaria were used further for identification.

Table-1: Study Area of Katihar District

\begin{tabular}{|c|c|c|c|}
\hline SITES & BLOCKS & VILLAGES & PONDS \\
\hline I & BARARI & $\begin{array}{l}\text { 1. Bisharia } \\
\text { 2. Ronia } \\
\text { 3. Laxmipur }\end{array}$ & $\begin{array}{l}\text { 1. Bisharia Pokhar/Pond } \\
\text { 2. Ronia Railway Dhala Pond } \\
\text { 3. Laxmipur Road Pond }\end{array}$ \\
\hline II & KORHA & $\begin{array}{l}\text { 4. Gorgamma } \\
\text { 5. Najra Chowki } \\
\text { 6.Pulwaria Chowk }\end{array}$ & $\begin{array}{l}\text { 4. Gorgamm Dhar / Pond } \\
\text { 5. Najra Chowki Pond } \\
\text { 6. Pulbaria Chowk Pond }\end{array}$ \\
\hline III & KATIHAR & $\begin{array}{l}\text { 7. Mania } \\
\text { 8. Kolasi } \\
\text { 9. Naya Tola }\end{array}$ & $\begin{array}{l}\text { 7. Mania Pond } \\
\text { 8. Kolasi Pond } \\
\text { 9. Naya Tola Pond }\end{array}$ \\
\hline
\end{tabular}




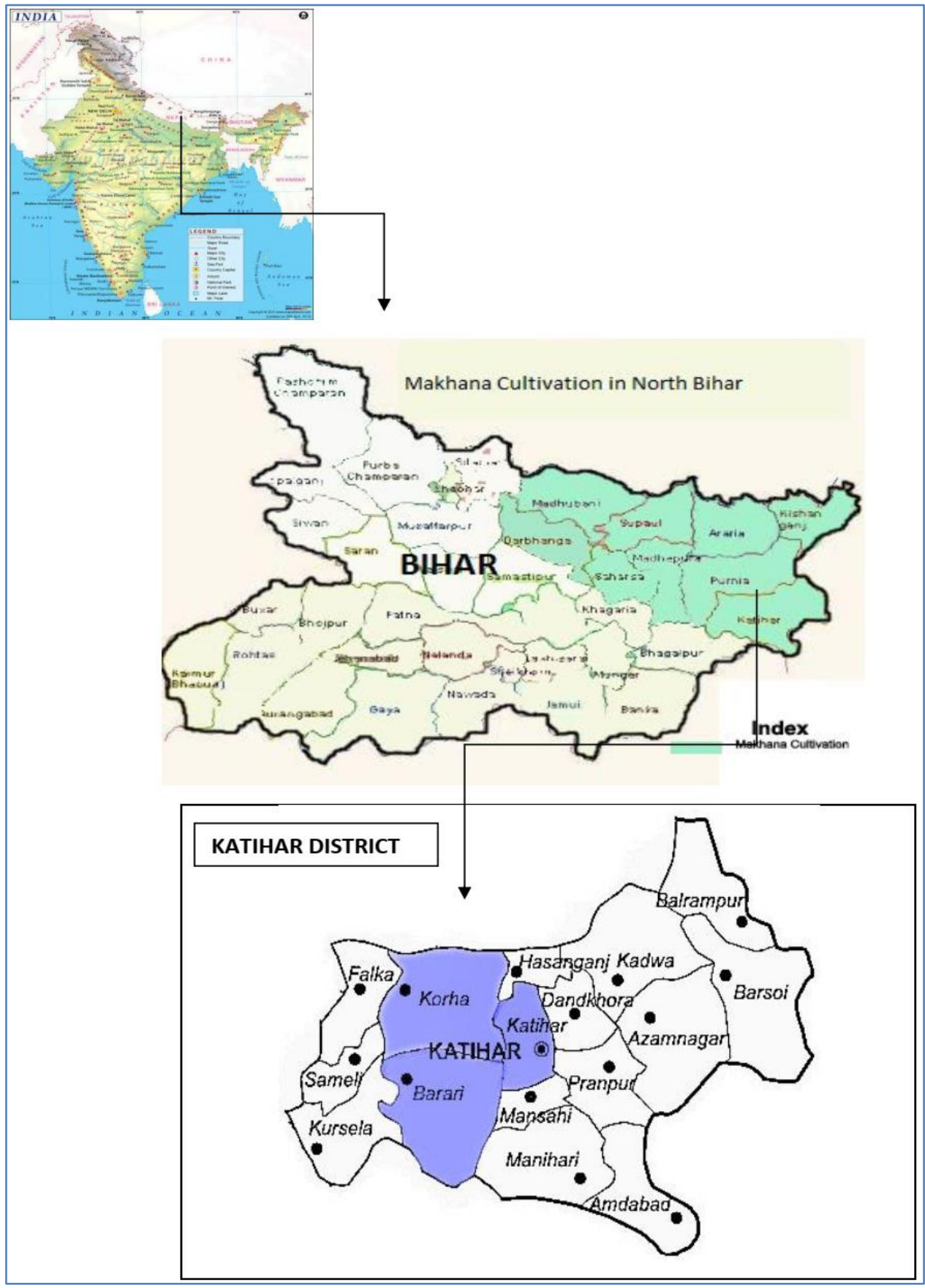

MAP - 1: LOCATION MAP OF KATIHAR DISTRICT IN BIHAR

\section{RESULTS AND DISCUSSION}

In Katihar district out of 16 blocks makhana cultivation is done mainly in 13 blocks.Based on thorough investigations of three blocks, makhana associated macrophytic weeds in Katihar district were classified as emergent, floating, submerged and subaerial. Association of different macrophytes with makhana in ponds of Katihar district are depicted in Table - 2. Seasonal fluctuations in abundance of other macrophytes associated with Makhana are depicted in Table - 3 . 
Table-2: Macrophyte Weeds Found in Association with E. ferox Salisb. In Katihar District

\begin{tabular}{|c|c|c|c|c|}
\hline Common Name & Botanical Name & Family & Class & Division \\
\hline \multicolumn{5}{|l|}{ Sub aerial } \\
\hline 1. Alligator weed & AIternanthera philoxeroide(Mart.) Griseb. & Amaranthaceae & Eudicots & Angiosperms \\
\hline 2. Water spinach & Ipomoea aquaticaForssk. & Convolvulaceae & Eudicots & Angiosperms \\
\hline 3. Water starworts & Limnophila heterophylla (Roxb.)Benth. & $\begin{array}{l}\text { Scrophulariaceae/P } \\
\text { lantaginacaea }\end{array}$ & Eudicots & Angiosperms \\
\hline 4. Frog fruit & Lippia nodiflora (L.) Greene & Verbenaceae & Eudicots & Angiosperms \\
\hline 5. Prime rose & Ludwigia sp.L. & Onagraceae & Eudicots & Angiosperms \\
\hline 5. Water clove & Marsilea quadrifolia L. & Marsileaceae & Polypodiopsida & Peridophyta \\
\hline 7. Leaf pond weed & Monocharia hastate (L.) Solms & Pontederiaceae & Monocots & Angiosperms \\
\hline 8. Knot grass & Polygonum hydropiperL. & Polygonaceae & Eudicots & Angiosperms \\
\hline 9. Khubahiramdana & Scirpus articultatus L. & Cyperaceae & Monocots & Angiosperms \\
\hline \multicolumn{5}{|l|}{ Submerged } \\
\hline 10. Shola pith plant & Aeschynomene aspera L. & Fabaceae & Eudicots & Angiosperms \\
\hline 11. Horn wort & Ceratophyllum demersum. L. & Ceratophyllaceae & Eudicots & Angiosperms \\
\hline 12. Water weed & Hydrilla verticillata (L.F.) Royle & Hydrocharitaceae & Monocots & Angiosperms \\
\hline 13. Watermilfoil & Myriophyllumsp.L. & Haloragaceae & Eudicots & Angiosperms \\
\hline 14. Water nymphs & Najas sp.L. & Hydrocharitaceae & Monocots & Angiosperms \\
\hline 15. Pond weed & Potamogeton crispusL. & Potamogetonaceae & Monocots & Angiosperms \\
\hline 16. Bladder worts & Utricularia sp. L. & Lentibulariaceae & Eudicots & Angiosperms \\
\hline 17. Tape grass & Vallisneria spiralisL. & Hydrocharitaceae & Monocots & Angiosperms \\
\hline \multicolumn{5}{|l|}{ Emergent } \\
\hline 18. Indian water fern & Ceratopteris thalictroides Brongniat & Pteridaceae & Polypodiopsida & Pteridophyta \\
\hline 19. Goose foot & Chenopodium sp.L. & Amaranthaceae & Eudicots & Angiosperms \\
\hline 20. Nut grass & Cyperus exaltatusRetz. & Cyperaceae & Monocots & Angiosperms \\
\hline 21. Rice flat sedge & CyperusiriaL. & Cyperaceae & Monocots & Angiosperms \\
\hline 22. Grass weed & Cyperus rotundus L. & Cyperaceae & Monocots & Angiosperms \\
\hline 23. Rusty grass & Fimbristylis sp.Vahl & Cyperaceae & Monocots & Angiosperms \\
\hline $\begin{array}{l}\text { 24. Ancient water } \\
\text { grass }\end{array}$ & $\begin{array}{l}\begin{array}{l}\text { Hygroryzaaristata(Retz.) Nees ex Wight } \\
\text { \&Arn. }\end{array}\end{array}$ & Poaceae & Monocots & Angiosperms \\
\hline 25. Goose berry & Physalissp.L. & Solanaceae & Eudicots & Angiosperms \\
\hline 26. Chichor & PolygonamsylvestrisL. & Polygonaceae & Eudicots & Angiosperms \\
\hline \multicolumn{5}{|l|}{ Floating } \\
\hline 27.Mosquito fern & Azollapinnata R. Br. & Salviniaceae & Polypodiopsida & Pteridophyta \\
\hline 28.Water hyacinth & Eichhorniacrassipes(Mart.) Solms & Pontederiaceae & Monocots & Angiosperms \\
\hline 29. Small duck weed & Lemnasp.L. & Araceae & Monocots & Angiosperms \\
\hline 30. Kamal gatta & NelumbonuciferaGaertn. & Nelumbonaceae & Eudicots & Angiosperms \\
\hline 31. Water lily & Nymphaea nouchaliBurm.f. & Nymphaeaceae & Eudicots & Angiosperms \\
\hline 32. Water & Pistia stratiotes L. & Araceae & Monocots & Angiosperms \\
\hline 33. Floating fern & Salvinianatans (L.) All. & Salviniaceae & Polypodiopsida & Pteridophyta \\
\hline 34. Duckweed & Spirodelapolyrhiza (L.) Schleid. & Araceae & Monocots & Angiosperms \\
\hline 35. Water meal & Wolffiaarrhizal (L.) Horkel ex Wimm. & Araceae & Monocots & Angiosperms \\
\hline
\end{tabular}

Table-3: Seasonal Fluctuations in Abundance of Macrophyte Weeds Associated with Makhana at Different Sites of Katihar District

\begin{tabular}{|c|c|c|c|c|c|c|c|c|c|}
\hline \multirow{2}{*}{ Name of Macrophytes } & \multicolumn{3}{|c|}{ Site-I } & \multicolumn{3}{|c|}{ Site-II } & \multicolumn{3}{|c|}{ Site-III } \\
\hline & $\mathbf{W}$ & $\mathbf{S}$ & $\mathbf{R}$ & $\mathbf{W}$ & $\mathbf{S}$ & $\mathbf{R}$ & $\mathbf{W}$ & $\mathbf{S}$ & $\mathbf{R}$ \\
\hline 1. Aeschynomene aspera L. & ++ & +++ & +++ & - & - & + & ++ & ++ & +++ \\
\hline 2. AIternanthera philoxeroide (Mart.) Griseb & ++ & + & +++ & ++ & + & +++ & ++ & + & +++ \\
\hline 3. Azolla pinnata R.Br. & +++ & + & ++ & ++ & +++ & + & +++ & + & + \\
\hline 4. Ceratophyllum demersum L. & +++ & +++ & +++ & +++ & +++ & +++ & +++ & +++ & +++ \\
\hline 5. Ceratopteris thalitroides (L.) Brongniart & - & - & - & + & + & ++ & + & + & ++ \\
\hline 6. Chenopodium sp. L. & + & + & +++ & - & - & - & + & ++ & +++ \\
\hline 7. Cyperus exaltatus Retz. & + & +++ & ++ & ++ & +++ & ++ & + & +++ & ++ \\
\hline 8. Cyperus iria L. & ++ & +++ & ++ & ++ & +++ & ++ & + & ++ & + \\
\hline 9. Cyprus rotundus L. & ++ & +++ & ++ & + & +++ & ++ & ++ & +++ & ++ \\
\hline 10. Eichhornia crassipes (Mart.) Solms & +++ & +++++ & ++++ & +++ & +++ & +++ & +++ & +++ & +++ \\
\hline 11.Fimbristyllis sp. Vahl & ++ & +++ & + & - & - & - & + & +++ & + \\
\hline 12. Hydrilla verticillata (L.F) Royle & ++ & +++ & ++ & +++ & +++ & +++ & ++ & +++ & ++ \\
\hline 13. Hygroryza aristata (Retz.) Nees ex Wight \& Arn. & ++ & +++ & + & ++ & +++ & + & - & - & - \\
\hline
\end{tabular}


Meenu Sodi \& Sanjib Kumar., Sch J Agric Vet Sci, Nov, 2020; 7(11): 231-239

\begin{tabular}{|c|c|c|c|c|c|c|c|c|c|}
\hline 14. Ipomoea aquatiaca Forssk. & +++ & +++ & ++ & +++ & +++ & ++ & +++ & +++ & ++ \\
\hline 15. Lemna sp. L. & +++ & + & ++ & + & ++ & + & +++ & + & ++ \\
\hline 16. Lippia nodiflora (L.) Greene & - & - & - & + & ++ & + & - & - & - \\
\hline 17.Limnophila heterophylla (Roxb.) Benth. & - & - & - & - & - & - & + & + & + \\
\hline 18. Ludwigia sp L. & ++ & + & +++ & ++ & +++ & ++ & ++ & + & +++ \\
\hline 19. Marsilea quadrifolia L. & +++ & +++ & +++ & & +++ & +++ & +++ & +++ & +++ \\
\hline 20. Monocharia hastata (L.) Solms & ++ & +++ & +++ & +++ & +++ & +++ & ++ & +++ & +++ \\
\hline 21. Myriophyllum sps. L. & ++ & +++ & ++++ & - & - & - & - & - & - \\
\hline 22. Najas sp.L. & ++ & +++ & +++ & + & + & ++ & ++ & ++ & +++ \\
\hline 23. Nelumbo nucifera Gaertn. & ++ & ++ & & & & & & & \\
\hline 24. Nymphaea nouchali Burm,f. & ++ & + & +++ & ++ & ++ & ++ & ++ & ++ & +++ \\
\hline 25. Pistia stratiotes L. & ++ & +++ & ++ & ++ & +++ & ++ & - & - & - \\
\hline 26.Potamogeton crispus L. & ++ & +++ & ++ & + & ++ & + & ++ & +++ & ++ \\
\hline 27. Polygonam sylvestris L. & + & + & + & - & - & - & - & - & - \\
\hline 28. Polygonum hydropiper L. & +++ & +++ & +++ & +++ & +++ & +++ & +++ & +++ & +++ \\
\hline 29. Physalis sp. L. & - & + & ++ & + & + & ++ & - & - & - \\
\hline 30. Salvinia natans (L.) All. & +++ & + & ++ & + & ++ & & +++ & + & ++ \\
\hline 31. Scirpus articultatus L. & + & +++ & +++ & + & ++ & ++ & + & + & + \\
\hline 32.Spirodela polyrhiza (L.) Schleid. & + & +++ & ++ & ++ & +++ & ++ & - & - & - \\
\hline 33. Utricularia sp. L. & + & ++ & + & - & - & - & - & - & - \\
\hline 34. Vallisneria spirailis L. & ++ & +++ & ++ & +++ & +++ & +++ & ++ & +++ & ++ \\
\hline 35..Wolffiaarrhiza (L.) Horkel ex Wimm. & +++ & ++ & ++ & ++ & +++ & + & +++ & ++ & ++ \\
\hline
\end{tabular}

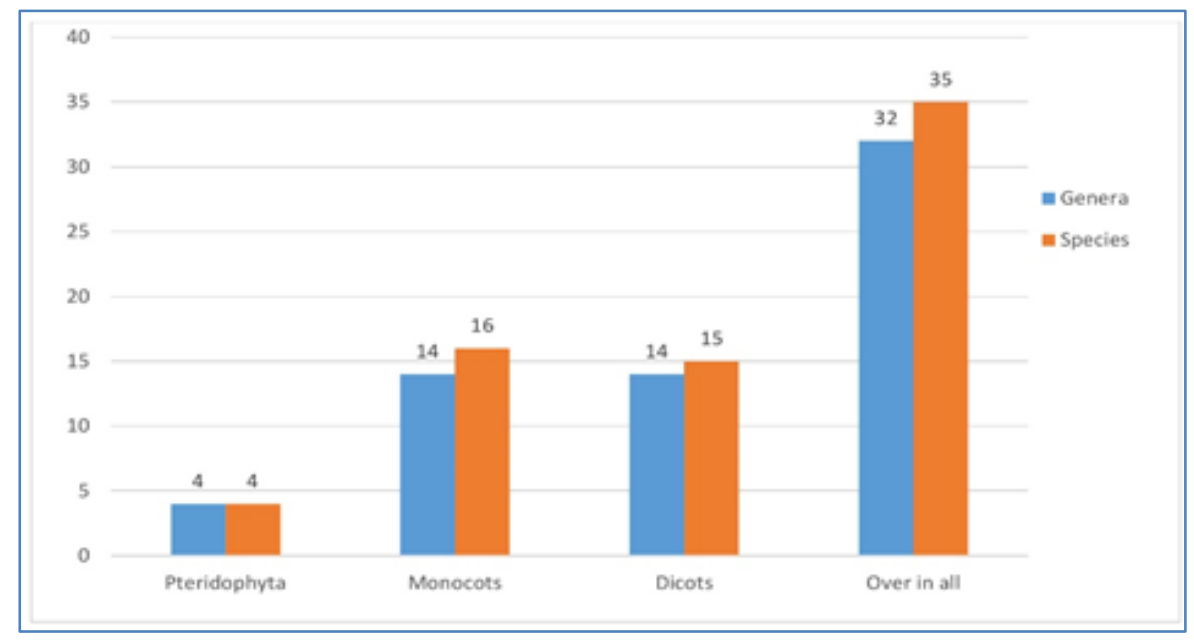

Fig-1: Total No.of Genera and Species of Macrophyte Weeds Found in Makhana Cultivated Ponds of Katihar District

Altogether 33 genera and 35 species of macrophytes were identified during the present study from different makhana cultivated ponds of Katihar disricts (Table - 1).Out of these macrophytes, angiosperms were represented by 29 genera and 31 species and pteridophytes by 4 genera and 4 species. Among angiosperms dicots were represented by 14 genera and 15 species and monocots by 14 genera and 16 species (Fig. - 1) Site - I exhibited the maximum number of genera (29) and species (32) followed by Site - II (26 genera and 26 species) and Site - III (25 genera and 25 species) respectively (Fig. -2). However, it was reported 11 species of aquatic macrophytes from the different ponds of Darbhanga [20]. 


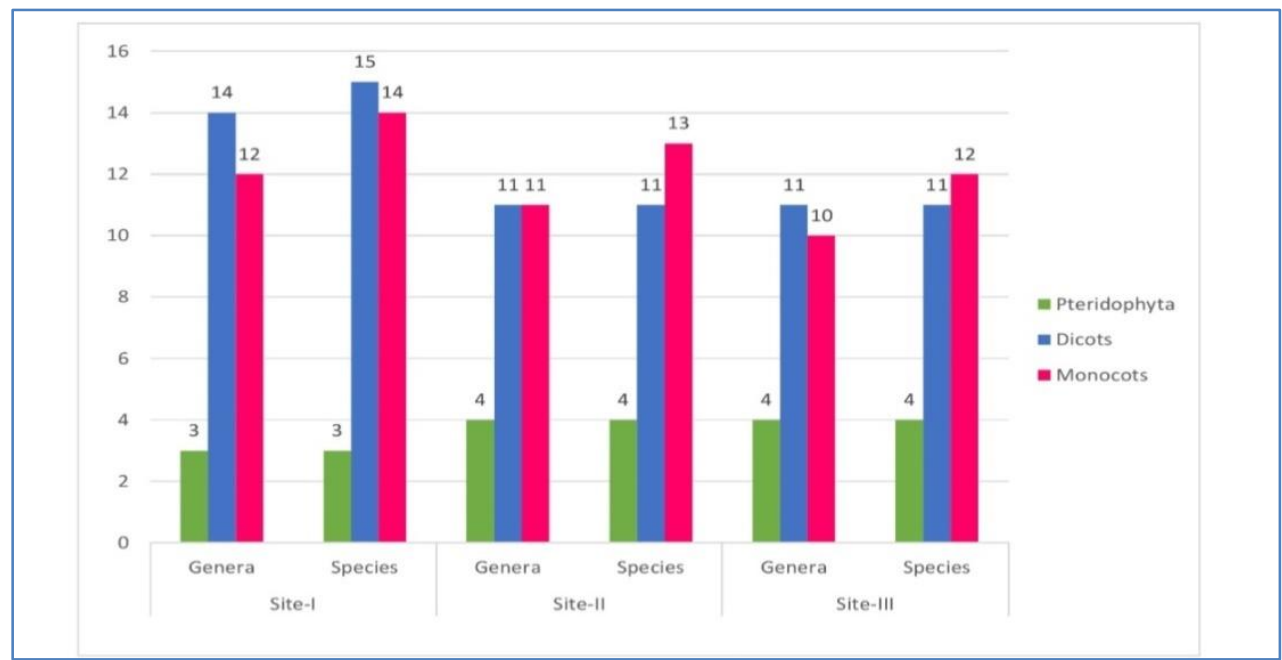

Fig-2: Total No. Of Genera and Species of Different Types of Macrophytes Found in Makhana Cultivated Ponds of Different Sites of Katihar District
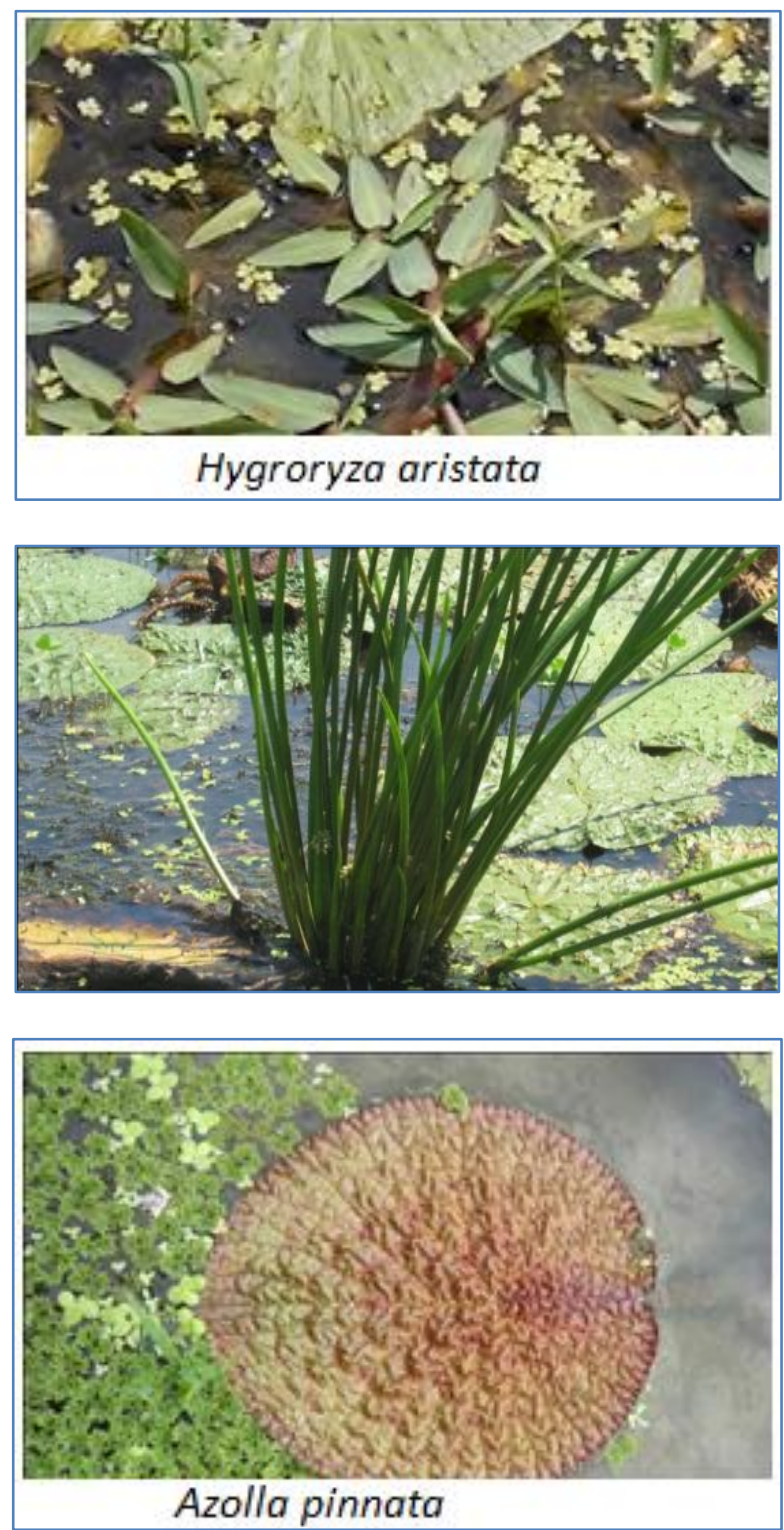
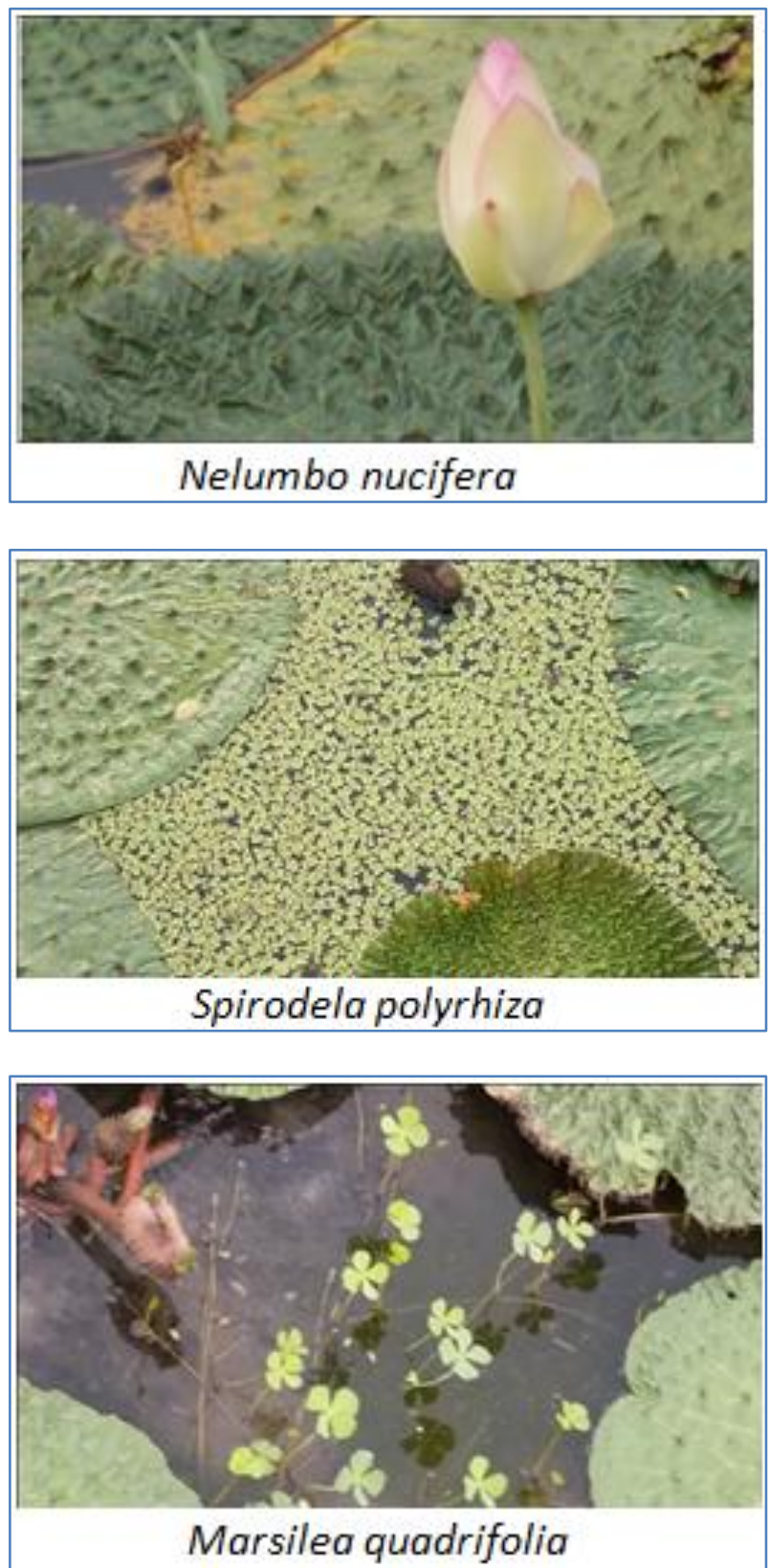

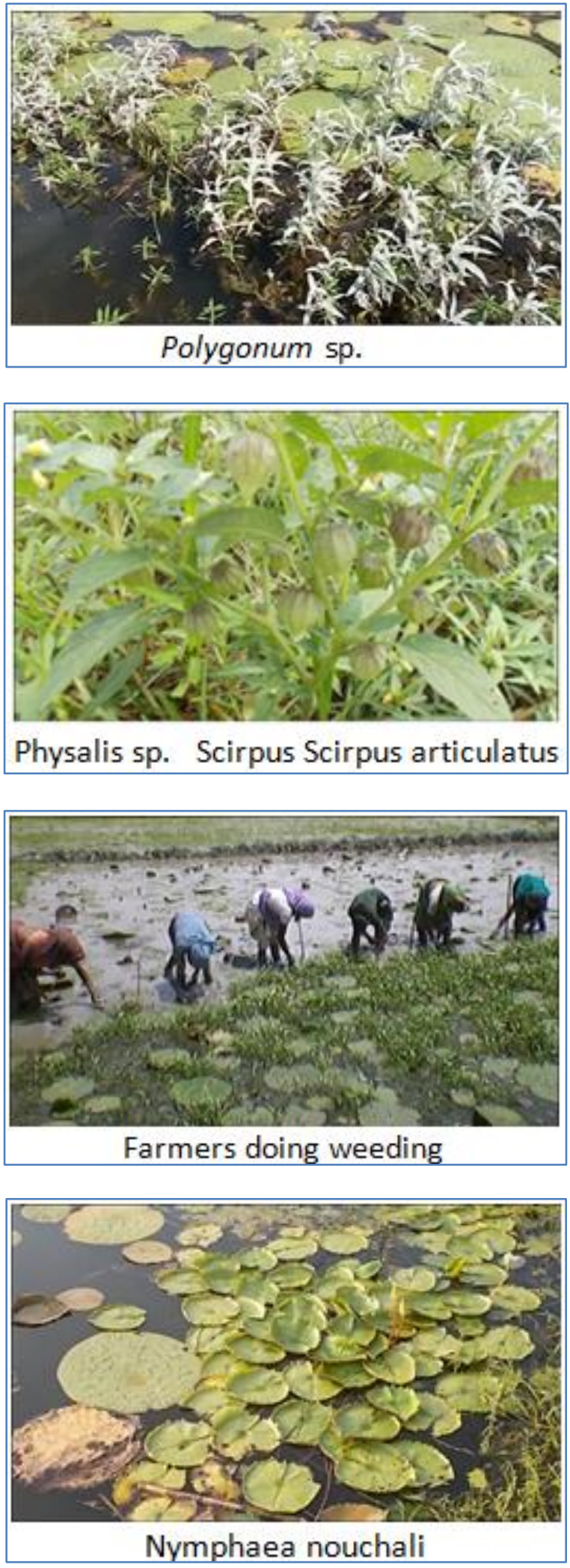

Plate-1: Macrophyte Weeds Associated with Makhana in Katihar District

Among different aquatic macrophytes 9 were emergent, 9 subaerial, 9 floating and 8 were submerged. Seasons had profound effects on the abundance of other macrophytes growing in association with makhana. Seasonal fluctuations showed maximum abundance of macrophytes during summer i.e. grand growth period of makhana closely followed by winter due to wide and favorable range of temperature, $\mathrm{pH}$, nutrients etc. However, the lowest abundance was recorded during rainy season i.e. during harvesting and post- harvesting period of makhana.

Ceratophyllum demersum, Hydrilla verticillata, Eichhornia carssipes, Monocharia hastata and Vallisneria spiralis were present throughout the year. Percentage frequency of $\mathrm{C}$. demersum, $\mathrm{H}$. verticillata, E. crassipes and Monocharia hastata showed maximum positive correlation with makhana (Table - 3). The dominant macrophytes recorded wereCyperus rotundus, C. exaltatus, Eichhorniacrassipes, Lemna sp., Azolla pinnata, Spirodela polyrhiza, Nymphaea nauchali, Nelumbo nucifera, Ceratophyllum demersum, Potamogeton crispus, Ludwigia sp., Polygonum hydropiper, P. sylvestris, Marsilea quadrifolia, Alternanthera philoxeroide, Ipomoea aquatica and Monocharia hastata.These macrophytes compete with makhana (E. ferox Salisb.) for nutrients, sunlight, space etc. and reduce the growth, increase the cost of labours and reduce the growth and yield of makhana plants. They cause damage in both the fields of agriculture and pisciculture. In our investigation some macrophytes like Nelumbonucifera, Nymphaeanauchali,

Eichhorniacrassipes, Aeschynomene aspera and Monocharia hastata were also observed as the most troublesome weeds.Cyperus defformis, C. rotundus, Hydrilla verticillata, Aeschynomene aspera and Sagittaria guayanesishave beenreported as the common weeds in Darbhanga which pose problems in makhana cultivation [8]. It is also reported that the main cause of the decline of makhana (E. ferox Salisb.) cultivation in West Bengal was the gregarious invasion of these macrophytes [21]. Some macrophytes associated with makhana grow up to maturity of makhana plants and are really competitors. But on the other hand several other macrophytes growing in association with makhana decay during the grand growth period and helpful in supplying nutrients of organic origin to the subsequent crops [22]. However, to obtain good growth of E. ferox Salisb. these macrophytes need to be removed from makhana cultivated ponds. Aquatic macrophytes also foster malaria, encephalitis and other mosquito borne diseases.

On the other hand, from ecological point of view these macrophytes provide shelter and refuges to periphytes[23], zooplankton [24], other invertabrates [25] and some other vertebrates like fishes and amphibians. They are also important for human beings as a source of food, biomass and building materials [26] as well therapeutic agents [27,28] and they also play a key role in biochemical cycles in aquatic system [22]. However, to obtain good growth of E. ferox Salisb. these macrophytes need to be removed from makhana 
cultivated ponds. Aquatic macrophytes also foster malaria, encephalitis and other mosquito borne diseases.

\section{CONCLUSIONS}

Macrophyte weeds pose problems in the cultivation of agricultural crops. Aquatic macrophytes like Nelumbo nucifera, Nymphaea nauchali, Eichhornia crassipes, Monocharia hastata, Aeschynomene aspera and some others act as weeds and pose a great threat to the cultivation of makhana in aquatic bodies. They compete for light, nutrients and space with makhana and reduce their growth and yield. Hence weeding of these macrophytes from makhana cultivated ponds or other aquatic systems are essential in earlier stages of development and establishment of makhana. This increases the cost of makhana production to the farmers. But on the other hand these macrophytes also provide nutrients to makhana plants after decaying during grand growth period of makhana i.e. in summer. Thus they play a vital role in biogeochemical cycling. Weed management is a serious problem for the cultivation of makhana crops. It has been found that cultivators usually destroy all aquatic weeds during cultivation of makhana crops. There is an increasing trends of use of chemical weedicides by the makhana cultivators which not only destroy obnoxious weeds but also some periphytes and smaller aquatic animals too. Therefore, mechanical weeding of only larger aquatic obnoxious macrophytes which grow up to the maturity of makhana crops like Nelumbo nucifera, Nymphaea nauchali, Eichhornia crassipes, Aeschynomene aspera, Monocharia hastata, Potamogeton crispus etc. in makhana ponds will be more beneficial from both agricultural and ecological point of views. Organic cakes of neem and castor may also be helpful. Some weeds germinate but their growth is suppreesed by the rapid growth of makhana crop which covers the entire field within the month. Smaller macrophytes do not create many problems as they require little nutrients, little spaces and light and finally occupy intermediate spaces between makhana leaves.

\section{ACKNOWLEDGEMENTS}

Authors are thankful to Prof. SK Varma (Ex HOD Botany) and Dr. Naresh Kumar (In-Charge Herbarium), TM Bhagalpur University, Bhagalpur, Bihar for identifying some of the specimens of aquatic macrophytes.

\section{REFERENCES}

1. Pramanik BR, Puste AM, Jana K, Banerjee K, Das DK, Dasgupta M. Makhana (Euryale ferox Salisb.)-cum-fish culture: An integrated management for better yield. Bangladesh Journal of Scientific and Industrial Research. 2013;48(4):281-6.

2. Goswami MM. Ecology of Euryale ferox Salisb. In flood plain wetlands of Assam. In Makhana. RK Mishra, Jha V and Dehadrai PV (Eds.) ICAR, New Delhi, 29-35.
3. Jha V, Barat GK, Jha UN. Nutritional evaluation of E. ferox Salisb. (Makhana). J Food Sci. Technol. 1990.

4. Puste AM. In: Agronomic Management of Wetland Crops. Kalyani Publishers, Ludhiana, India. 2004.

5. Verma AM, Jha V, Ahmad SH. Fish- Makhana (Euryaleferox Salisb.) integration - a case study of sustainable aquafarming system a north Bihar. J Indian Fish Assoc. 2008; 35; 87-96.

6. Kumari Anubha, Jha V. Ethnic uses of makhana (Euryaleferox Salisb.) in Mithila and other parts of India. Journal of Traditiopnal and Folk Practies. 2017; 5(1): 60-74.

7. Sodi Meenu, Kumar Sanjib. Integrated MakhanaFish aquaculture: A sustainable approach for poverty alleviation and livelihood in the rural areas of North-Eastern Bihar. Scholars Journal of Agriculture and Veterinary Sciences. 2019; 6(4): 119-127.

8. Jana BR. Impact of water depth on growth of gorgon nut and associated weed under wetland ecosystem of North Bihar province in India. Journal of Crop and Weed. 2017; 13(1). 77-82.

9. Udyog Mitra. Businessplan of makhana cluster in Bihar www udhyogmitra/asserts/uploads/2012/06/makhanareport.pdf. 2012.

10. Panigrahy S, Murthy TV, Patel GJ, Suthar NM, Kundu N, Paul M, Basu N. National wetland atlas: Bihar. Space Applications Centre (ISRO), Ahmedabad and Institute of Environmental Studies and Wetland Management (IESWN), Kolkata. 2010; 222.

11. Kumar U, Kumar A, Singh KM. Constrant and drudgery in Makhana cultivation. International Journal of Extention Education. 7: 47-51

12. Ghose SKR, Santra SC. Past and present distribution records of Makhana and future prospects and its cultivation in West Bengal. In Makhana, RK Mishra, V Jha, PV Dehadrai (Eds.), ICAR, New Delhi. 2003: 3-7.

13. RN Dutta. Comparative Ecological Study of Euryaleferox Salisb. In Darbhanga area. Ph.D. Thesis, Ranchi University Ranchi, Bihar; 1984.

14. AK Laal, Munsi JSD. Biology and habitat ecology of Euryaleferox Salisb. In: Makhana, RK Mishra, Vidyanath Jha and PV Dehadri (Eds.), ICAR, New Delhi. 2003; 36-41.

15. Haines HH. The Botany of Bihar and Orissa. Part II: $22 ; 1925$.

16. Biswas K, Cadler C. Handbook of Common Water and Marsh Plants of India. Government of India Press, Calcutta:216;1936

17. Subramaniam K. AquaticAngiosperms. CSIR: 68; 1962.

18. Gopal B (Ed.). Ecology and Management of Aquatic Vegetation in Indian Sub-Continent. Kluwer Acad. Publisher. The Netherlands; 1910. 
19. Naskar. Aquatic and Semi Aquatic Plants of lower Ganga Delta: Its Taxonomy, Ecology and Economic Importance. Daya Publishing House, Delhi. 1990; 408.

20. Siddiqui EN, Singh JK, Ahmad SS. Comparative ecology of Euryale ferox Salisb. In North Bihar Ponds. In Makhana, RK Mishra, V Jha, PV Dehadrai (Eds), ICAR, New Delhi.

21. Ghose SK. Studies in the ecology of aquatic plant communities in West Bengal, India. Ph.D. Thesis, Kalyani University, West Bengal.1994.

22. Marion L, Paillison JM. A mass balance assessment of the contribution of floating-leaved macrophytes in nutrient stocks in a eutrophic macrophyte-dominated lake. AquaticBotany. 2002; 75: 249-260.

23. Carpenter SR, Lodge DM. Effects of submerged macrophytes on ecosystem processes. AquaticBotany. 1986; 26: 341-370.

24. Stansfield JH, Perrow MR, Tench LD, Jowitt AJ, Taylor AA. Submerged macrophytes as refuges for grazing in relation to macrophyte cover and predation pressure. Cladocera against fish predation: observations on seasonal changes. Hydrobiologia. 1997; 119: 229-240.

25. Dvorak J, Best EPH. Macro-invertabrate communities associated with the macrophytes of Lake Vachetan: structural and functional relationships. Hydrobiologia. 1982; 95: 115-126.

26. Engelhard KAM, Ritchie ME. Effects of macrophyte species richness on wetland ecosystem functioning and services. Nature. 2001; 411: 687-689.

27. Jha Vidyanath, Shalini Rachana, Kumari Anubha, Jha Prajna, Sah Nand K. Aquacultural, nutritional and therapeutic biology of delicious seeds of Euryale ferox Salisb: A mini review. Current Pharmaceutical Biotechnology. 2018; 19(7): 545-555.

28. Chai TT, Ooh KF, Quah Y, Wong FC. Edible freshwater macrophytes: a source of anticancer and antioxidative natural products - a minireview. Phytochemistry Reviews. 2015 Jun 1;14(3):443-57. 